\title{
UPAYA PENINGKATAN MOTIVASI BELAJAR SISWA MELALUI METODE PROBLEM SOLVING PADA MATA PELAJARAN PPKN DI KELAS XI
}

\author{
MAMIK ISGIYANTI \\ Madrasah Aliyah Negeri 1 Jember \\ e-mail: mamik941@gmail.com
}

\begin{abstract}
ABSTRAK
Penelitian ini dilatarbelakangi oleh adanya permasalahan, yaitu rendahnya motivasi siswa dalam pembelajaran PPKn yang disebabkan salah satunya karena penggunaan metode pembelajaran yang cenderung monoton, kurang menarik dan merangsang siswa untuk berpikir sehingga mengakibatkan motivasi belajar siswa kurang atau rendah. Sehubungan dengan itu maka Penerapan metode problem solving diharapkan dapat meningkatkan motivasi belajar siswa, karena metode problem solving dapat merangsang siswa untuk berpikir, menganalisis, menemukan, dan memecahkan masalah. Tujuan penelitian ini adalah untuk memperbaiki proses pembelajaran dan meningkatkan motivasi siswa dalam pembelajaran PPKn. Rancangan penelitian yang digunakan adalah penelitian tindakan kelas dengan dua siklus, dan tiap siklus dua pertemuan. Data penelitian berupa hasil pengamatan dan angket. Penelitian ini dilaksanakan di MAN 1 Jember dengan subjek penelitian kelas XI MIPA-3. Hasil penelitian ini menunjukkan bahwa ada peningkatan motivasi belajar siswa dengan penerapan metode problem solving. Pada tahap pratindakan motivasi belajar siswa mencapai skor 7,80 dengan rata-rata 1,95 yang artinya motivasi belajar siswa rendah. Pada siklus 1 jumlah skor 9,08 dengan rata-rata 2,27 yang artinya motivasi belajar sedang. Pada siklus 2 jumlah skor 12,09 dengan rata-rata 3,02 yang artinya motivasi belajar tinggi.
\end{abstract}

Kata Kunci: Motivasi Belajar, Problem Solving, Pembelajaran PPKn

\section{ABSTRACT}

This research is motivated by the existence of problems, namely the low motivation of students in learning Civics which is caused by the use of learning methods that tend to be monotonous, less attractive and stimulate students to think, resulting in less or low student motivation. In this regard, the application of problem solving methods is expected to increase students' learning motivation, because problem solving methods can stimulate students to think, analyze, find, and solve problems. The purpose of this research is to improve the learning process and increase student motivation in learning Civics. The research design used was classroom action research with two cycles, and each cycle had two meetings. Research data in the form of observations and questionnaires. This research was conducted at MAN 1 Jember with the research subject of class XI MIPA-3. The results of this study indicate that there is an increase in students' learning motivation with the application of problem solving methods. At the pre-action stage, students' learning motivation reached a score of 7.80 with an average of 1.95 , which means that students' motivation is low. In cycle 1 the total score is 9.08 with an average of 2.27 , which means that learning motivation is moderate. In cycle 2 the total score is 12.09 with an average of 3.02, which means high learning motivation.

Keywords: Learning Motivation, Problem Solving, PPKn Learning

\section{PENDAHULUAN}

PPKn merupakan salah satu mata pelajaran yang diberikan di sekolah dari tingkat sekolah dasar sampai menengah. Pembelajaran PPKn pada sekolah menengah atas dimaksudkan untuk mengembangkan kemampuan-kemampuan terutama dalam ranah afektif yang terkait dengan kehidupan bermasyarakat dan bernegara. Hal ini selaras dengan pernyataan PP Nomor 32 Tahun 2013, bahwa Pendidikan Kewarganegaran dimaksudkan untuk membentuk peserta didik menjadi manusia yang memiliki rasa kebangsaan dan cinta tanah air dalam konteks nilai dan 
moral Pancasila, kesadaran berkonstitusi UUD Negara Republik Indonesia Tahun 1945, nilai dan semangat Bhinneka Tunggal Ika, serta komitmen Negara Kesatuan Republik Indonesia.

Oleh karena itu sangat diharapkan guru PPKn mampu menciptakan suasana pembelajaran yang mengarah pada terbentuknya karakter siswa sesuai dengan yang selaras dengan Pancasila dan UUD 1945. Akan tetapi riil di lapangan pembelajaran PPKn lebih cenderung menitikberatkan pada penguasaan aspek pengetahuan dan mengabaikan pengembangan sikap dan keterampilan kewarganegaraan, sehingga terkesan PPKn bersifat teoritis, abstrak, dan membosankan, sehingga siswa dalam mengikuti pembelajaran PPKn tersebut kurang antusias, kadangkala berbicara sendiri dengan teman, bermain HP, tidak memperhatikan guru, bahkan lebih dari itu siswa banyak yang mengantuk ketika mengikuti pembelajaran PPKn. Kondisi tersebut menunjukkan bahwa para siswa tidak memiliki motivasi dalam mengikuti pembelajaran PPKn.

Banyak faktor yang menjadi penyebab terciptanya kondisi seperti itu. Dari cara guru menyajikan materi yang kurang menarik, penggunaan metode yang cenderung monoton dan kurang bisa merangsang siswa untuk berpikir kritis, sumber belajar yang terbatas, dan tidak adanya media pembelajaran. Dalam pembelajaran guru seringkali hanya menggunakan metode ceramah tanpa ada variasi yang lain, sehingga siswa kurang berminat dalam mengikuti pelajaran. Guru tidak memiliki kreativitas untuk melakukan hal-hal yang dapat membangkitkan motivasi para siswa agar lebih bergairah dalam mengikuti pelajaran. Semua itu dapat membuat motivasi belajar siswa dalam pembelajaran PPKn menjadi rendah.

Sebenarnya banyak hal yang dapat dilakukan oleh seorang guru untuk menciptakan suasana pembelajaran menjadi lebih menyenangkan bagi anak. Melalui penerapan modelmodel pembelajaran, guru dapat memilih model pembelajaran yang dapat membangkitkan motivasi belajar siswa. Salah satunya adalah metode problem solving. Dengan metode ini siswa diajak untuk berpikir tentang suatu persoalan yang dapat diselesaikan secara mandiri atau kelompok.

Metode problem solving merupakan cara mengajar yang merangsang seseorang untuk menganalisa dan melakukan sintesa dalam kesatuan struktur atau situasi di mana masalah itu berada (Djajadisastra, 1982: 19-20). Metode ini mengajak siswa untuk berfikir, menganalisis, menemukan dan memecahkan masalah. Salah satu kelebihan dari metode pemecahan masalah adalah siswa menjadi aktif, berinisiatif dan bertanggung jawab (Hamdani, 2011: 86). Oleh karena itu penulis berharap dengan metode tersebut dapat digunakan untuk mengatasi rendahnya motivasi siswa dalam pembelajaran PPKn.

Telah dilakukan beberapa penelitian tentang metode pembelajaran problem solving. Mukhlisoh dan Aisah (2014) menyimpulkan bahwa dengan menggunakan metode problem solving memberikan pengaruh positif dan signifikan terhadap motivasi belajar siswa. Dewi et al (2018) dalam penelitiannya menyatakan bahwa model problem solving efektif dan memiliki ukuran pengaruh besar dalam meningkatkan motivasi belajar dan penguasaan konsep siswa. Penelitian Mukhlis (2017) juga menyatakan bahwa dengan model problem solving dapat meningkatkan motivasi belajar siswa.

Berdasarkan latar belakang di atas, ada dua permasalahan yang diangkat dalam penelitian ini, yaitu 1) Apakah penggunaan metode problem solving dapat meningkatkan motivasi belajar siswa pada mata pelajaran PPKn kelas XI MIPA-3 Tahun Pelajaran 20182019?; 2) Bagaimana metode problem solving dapat meningkatkan motivasi belajar siswa pada mata pelajaran PPKn kelas XI MIPA-3 Tahun Pelajaran 2018-2019?

Adapun tujuan dari penelitian ini mengacu pada permasalahan di atas adalah untuk mengetahui apakah penggunaan metode problem solving dapat meningkatkan motivasi belajar siswa pada mata pelajaran PPKn dan untuk mengetahui bagaimana metode problem solving dapat meningkatkan motivasi belajar siswa pada mata pelajaran PPKn. 


\section{METODE PENELITIAN}

Penelitian ini menggunakan rancangan penelitian tindakan kelas dengan pendekatan deskriptif kualitatif dan kuantitatif. Data yang didapat dari observasi pada saat pelaksanaan pembelajaran dengan metode problem solving dianalisis secara kualitatif, sedangkan data dari angket motivasi belajar yang diisi oleh siswa dianalisis secara kuantitatif yaitu dimasukkan dalam format penilaian, diprosentase, dan dihitung skor rata-ratanya untuk dikategorikan dalam klasifikasi motivasi rendah, sedang, atau tinggi. Kemudian dideskripsikan berupa kata-kata atau kalimat. Dengan itu guru akan mengetahui motivasi belajar siswa dalam mata pelajaran PPKn

Penelitian tindakan kelas ini dilaksanakan di MAN 1 Jember pada bulan Juli sampai dengan Oktober tahun pelajaran 2018-2019, dengan rincian sebagai berikut:

a. Persiapan, dilaksanakan pada minggu ke-3 bulan Juli sampai dengan minggu ke-2 bulan Agustus 2018

b. Pelaksanaan tindakan, pada minggu ke-3 bulan Agustus sampai dengan minggu ke-3 bulan September 2018

c. Pengumpulan data, pada bulan September sampai dengan minggu ke-4 bulan September 2018

d. Analisa data, pada minggu 1 Oktober 2018

e. Pembuatan laporan, pada minggu ke-2 Oktober 2018

Subyek penelitian tindakan kelas ini adalah siswa kelas XI MIPA-3 MAN 1 Jember pada Semester Ganjil Tahun Pelajaran 2018-2019, yang berjumlah 34 siswa dengan komposisi 23 perempuan dan 11 laki-laki. Kelas ini dipilih sebagai subyek penelitian karena memiliki karakteristik motivasi belajar siswanya rendah pada saat pembelajaran PPKn dan guru menggunakan metode pembelajaran yang bersifat satu arah

Pelaksanaan penelitian ini ada dua tahap kegiatan, yaitu tahap pratindakan dan tahap pelaksanaan tindakan. Pada tahap pratindakan kegiatan yang dilakukan peneliti antara lain: melakukan observasi awal, yaitu mengobservasi kegiatan pembelajarn yang telah dilaksanakan oleh guru sesuai dengan RPP yang telah direncanakan, mengumpulkan data atau permasalahan, mengukur motivasi belajar siswa, dan merefleksi. Selanjutnya pada tahap pelaksanaan tindakan dilakukan dengan menggunakan dua siklus. Setiap siklus terdiri dari dua kali pertemuan, dan masing-masing siklus meliputi perencanaan, tindakan, pengamatan, dan refleksi

Sumber data dalam penelitian ini diperoleh dari siswa, guru, dan kolabolator. Adapun teknik pengumpulan data yang digunakan yaitu: 1) Angket untuk mengukur motivasi belajar siswa dengan menggunakan intrumen daftar pertanyaan yang terdiri dari empat indikator, yaitu Attention, Relevance, Confidence, Satisfaction. Dari indikator tersebut dikembangkan menjadi 26 item pernyataan, kemudian hasil perhitungan skor angket dibuat kategori, rendah, sedang, tinggi. Dalam Angket disediakan pilihan jawaban sangat setuju, setuju, ragu-ragu, tidak setuju, sangat tidak setuju; 2) Observasi dengan menggunakan instrumen lembar pengamatan untuk mengamati aktivitas guru dan siswa. Dalam lembar pengamatan disediakan pilihan kualifikasi sangat baik, baik, cukup baik, dan kurang baik.

Indikator keberhasilan dalam penelitian ini adalah apabila dengan menggunakan metode problem solving dapat meningkatkan motivasi belajar siswa. Adapun untuk mengukur keberhasilan tersebut, yaitu apabila skor rata-rata dari empat indikator mencapai $>3,00$.

\section{HASIL DAN PEMBAHASAN}

\section{Hasil}

Pratindakan

Pada tahap pratindakan, guru melakukan pengamatan terhadap proses pembelajaran PPKn di kelas XI MIPA-3. yang mana guru masih menggunakan metode konvensional yaitu ceramah dan pemberian tugas dan tanpa menggunakan media pembelajaran Setelah berakhirnya pembelajaran tersebut guru memberikan angket untuk mengukur motivasi belajar siswa terhadap pembelajaran PPKn. 
Tabel 1. Hasil Pengukuran Motivasi Belajar pada Pratindakan

\begin{tabular}{llcccccc}
\hline No & \multicolumn{1}{c}{ Indikator } & \multicolumn{7}{c}{ Skor } \\
\hline & & Tinggi & $(\%)$ & Sedang & $(\%)$ & Rendah & $(\%)$ \\
\hline 1 & Perhatian & 1 & 2,94 & 11 & 32,35 & 22 & 64,71 \\
2 & Kesesuaian & 2 & 5,88 & 4 & 11,77 & 28 & 82,35 \\
3 & Kepercayaan & 1 & 2,94 & 8 & 23,53 & 25 & 73,53 \\
4 & Kepuasan & - & 0 & 5 & 14,71 & 29 & 85,29 \\
\hline
\end{tabular}

Pembelajaran pada tahap pratindakan menunjukkan indikator perhatian (attention) dari 34 siswa terdapat $1(2,94 \%)$ siswa yang memiliki perhatian tinggi, $11(32,35 \%)$ siswa yang memiliki perhatian sedang, dan $22(64,71 \%)$ siswa yang memiliki perhatian rendah. Indikator kesesuaian (relevance) dari 34 siswa, terdapat $2(5,88 \%)$ siswa yang memiliki kesesuaian tinggi, 4 ( $11,77 \%)$ siswa yang memiliki kesesuaian sedang, dan $28(82,35 \%)$ yang memiliki kesesuaian rendah. Indikator kepercayaan diri (confidence) dari 34 siswa terdapat $1(2,94 \%)$ siswa yang memiliki kepercayaan diri yang tinggi, $8(23,53 \%)$ siswa yang memiliki kepercayaan diri sedang, dan $25(73,53 \%)$ siswa yang memiliki kepercayaan diri rendah. Indikator kepuasan (satisfaction) dari 34 siswa tidak terdapat siswa yang memiliki kepuasaan tinggi, terdapat $5(14,71 \%)$ siswa yang memiliki kepuasan sedang, dan $29(85,29 \%)$ siswa yang memiliki kepuasan rendah

Tabel 2. Skor Rata-rata

\begin{tabular}{clc}
\hline No & Indikator & rata-rata \\
\hline 1 & Perhatian & 2,00 \\
2 & Kesesuaian & 1,92 \\
3 & Kepercayaan & 1,98 \\
4 & Kepuasan & 1,90 \\
& Jumlah & 7,80 \\
& Rata-rata & 1,95 \\
\hline
\end{tabular}

Hasil angket pada tahap pratindakan menunjukkan bahwa motivasi belajar siswa pada mata pelajaran PPKn tahap pratindakan skornya 7,80 dengan rata-rata skor 1,95 yang artinya motivasi belajarnya rendah. Hal ini disebabkan karena pembelajaran yang dilakukan masih berpusat pada guru bukan pada siswa, guru tidak menggunakan media pembelajaran sehingga pembelajaran menjadi kurang menarik, guru kurang memberikan penguatan, guru masih menggunakan metode konvensional yaitu ceramah yang tidak bervariatif

\section{Siklus I}

\section{Pertemuan 1}

Pembelajaran pada siklus I dilaksanakan dua kali pertemuan. Kompetensi untuk pertemuan pertama adalah tentang kasus-kasus pelanggaran HAM dengan materi pokok pengertian dan bentuk-bentuk pelanggaran HAM, dan pertemuan kedua tentang kasus-kasus pelanggaran HAM di Indonesia Pada kegiatan pembelajaran pertemuan pertama, guru melakukan hal-hal sebagai berikut:

a. Guru menyampaikan salam

b. Guru mennyampaikan pokok bahasan yang akan dibahas

c. Guru menjelaskan secara singkat tentang pengertian dan bentuk-bentuk pelanggaran HAM

d. Guru menjelaskan langkah-langkah metode problem solving

e. Guru membentuk kelompok dengan cara berhitung $1-5$, kemudian nomor yang sama bergabung menjadi satu kelompok. Jumlah kelompok yang terbentuk sebanyak 7 kelompok dengan anggota masing-masing 5 (lima) siswa, dan ada 1 (satu) kelompok beranggotakan 4 (empat) siswa. 
f. Guru mengarahkan siswa untuk mengerjakan tugas secara kelompok

g. Siswa mendiskusikan masalah yang sudah diterima sesuai dengan langkah-langkah belajar motode problem solving dan menuliskan hasilnya pada kertas yang telah disediakan

h. Guru memantau jalannya diskusi kelompok secara berkeliling pada masing-masing kelompok

i. $\quad 20$ menit kemudian, masing-masing kelompok mempresentasikan hasil diskusinya

j. Siswa mengumpulakn lembar kerja hasil diskusi masing-masing kelompok yang telah dipresentasikan

k. Guru melakukan evaluasi jalannya diskusi

1. Guru menutup pelajaran dengan mengucapkan salam.

m. Guru membagikan angket kepada siswa.

Tabel 3. Hasil Pengukuran Motivasi Belajar Siklus 1 Pertemuan 1

\begin{tabular}{llcccccc}
\hline No & \multicolumn{1}{c}{ Indikator } & \multicolumn{6}{c}{ Skor } \\
\hline & & Tinggi & $(\%)$ & Sedang & $(\%)$ & Rendah & $(\%)$ \\
\hline 1 & Perhatian & 2 & 5,88 & 19 & 55,88 & 13 & 38,24 \\
2 & Kesesuaian & 2 & 5,88 & 10 & 29,41 & 22 & 64,71 \\
3 & Kepercayaan & 1 & 2,94 & 22 & 64,71 & 11 & 32,35 \\
4 & Kepuasan & 1 & 2,94 & 21 & 61,77 & 12 & 35,29 \\
\hline
\end{tabular}

Pada siklus 1 pertemuan 1, indikator perhatian (attention) dari 34 siswa terdapat $2(5,88$ $\%)$ siswa yang memiliki perhatian tinggi, 19 (55,88 \%) siswa yang memiliki perhatian sedang, dan $13(38,24 \%)$ siswa yang memiliki perhatian rendah.Indikator kesesuaian (relevance) dari 34 siswa, terdapat $2(5,88 \%)$ siswa yang memiliki kesesuaian tinggi, $10(29,41 \%)$ siswa yang memiliki kesesuaian sedang, dan $22(64,71 \%)$ yang memiliki kesesuaian rendah.Indikator kepercayaan diri (confidence) dari 34 siswa terdapat $1(2,94 \%)$ siswa yang memiliki kepercayaan diri yang tinggi, $22(64,71 \%)$ siswa yang memiliki kepercayaan diri sedang, dan $11(32,35 \%)$ siswa yang memiliki kepercayaan diri rendah.Indikator kepuasan (satisfaction) dari 34 terdapat $1(2,94 \%)$ siswa yang memiliki kepuasaan tinggi, terdapat $21(61,77 \%)$ siswa yang memiliki kepuasan sedang, dan $12(35,29 \%)$ siswa yang memiliki kepuasan rendah

Tabel 4. Skor Rata-rata

\begin{tabular}{clc}
\hline No & \multicolumn{1}{c}{ Indikator } & rata-rata \\
\hline 1 & Perhatian & 2,23 \\
2 & Kesesuaian & 2,10 \\
3 & Kepercayaan & 2,20 \\
4 & Kepuasan & 2,14 \\
& Jumlah & 8,67 \\
& Rata-rata & 2,17 \\
\hline
\end{tabular}

Dari data diatas dapat diketahui bahwa motivasi siswa pada siklus I pertemuan 1 jumlah skornya adalah 8,67 dengan rata-rata skor 2,17 yang artinya motivasinya sedang. Pada siklus I pertemuan 1 motivasi belajar siswa pada mata pelajaran PPKn mengalami peningkatan dari sebelum tindakan skor rata-rata 1,95 meningkat setelah dilakukan tindakan menjadi 2,17.

Berdasarkan hasil pengamatan aktivitas guru dan siswa selama proses pembelajaran, peningkatan ini terjadi karena guru sudah menggunakan metode problem solving dalam proses pembelajaran. Akan tetapi peningkatan motivasi belajar ini masih dalam kategori sedang. Hal ini disebabkan karena guru dalam menerapkan metode problem solving kurang atau tidak melakukan beberapa hal yaitu menyampaikan tujuan, memberikan apersepsi, memberikan contoh dan melatih penerapan metode problem solving, serta memeriksa pemahaman siswa terhadap metode problem solving, sehingga terkesan mayoritas siswa masih kebingungan 
dalam menerapkan metode problem solving. Dari ketidakpahaman terhadap metode problem solving menjadikan siswa lebih banyak pasif dan diam.

\section{Pertemuan 2}

Pelaksanaan kegiatan belajar mengajar dilaksanakan sesuai dengan rencana pembelajaran yang telah dibuat terbagi dalam tiga bagian, yaitu pendahuluan, kegiatan inti, dan penutup. Untuk lebih jelasnya diuraikan sebagai berikut.

Kegiatan pembelajaran pada pertemuan 2 diawali dengan mengucapkan salam, dan memberikan motivasi untuk membangkitkan semangat siswa. Kemudian guru melakukan apersepsi dengan bertanya, "Bagaimana kasus pelanggaran HAM yang terjadi di Indonesia saat ini?" Siswa menjawab lagi marak. Kemudian guru melanjutkan pertanyaan, "Apa yang menyebabkan makin maraknya kasus pelanggaran HAM di Indonesia?" Jawaban siswa bervariasi dengan alasan yang juga bervariasi. Dari situ guru menggiring siswa ke materi yang akan dibahas dalam pertemuan itu.

Tahap berikutnya guru menyampaikan tujuan pembelajaran. Selanjutnya secara garis besar guru menjelaskan inti materi dengan dibantu media pembelajaran yang sudah dipersiapkan. Kemudian guru mengingatkan kembali metode problem solving yang sudah diterapkan pada pertemuan sebelumnya. Guru mempertegas kembali bagaimana langkahlangkah dari metode problem solving, dan siswa ditanya apakah sudah paham dengan metode tersebut. selanjutnya guru membentuk kelompok menjadi 7 kelompok dengan cara undian. Guru mempersilahkan siswa mengambil kertas yang sudah diberi huruf. Siswa yang memperoleh huruf yang sama menjadi satu kelompok. Kemudian guru mempersilahkan untuk mengatur tempat kelompok secara melingkar. Tahap berikutnya guru membagikan LKS kepada setiap kelompok untuk dikerjakan dengan langkah-langkah problem solving dan seterusnya seperti pada pertemuan 1 .

Tabel 5. Hasil Pengukuran Motivasi Belajar Siklus 1 Pertemuan 2

\begin{tabular}{llcccccc}
\hline No & \multicolumn{1}{c}{ Indikator } & \multicolumn{6}{c}{ Skor } \\
\hline & & Tinggi & $(\%)$ & Sedang & $(\%)$ & Rendah & $(\%)$ \\
\hline 1 & Perhatian & 7 & 20,59 & 20 & 58,82 & 7 & 20,59 \\
2 & Kesesuaian & 6 & 17,64 & 13 & 38,24 & 15 & 44,12 \\
3 & Kepercayaan & 4 & 11,77 & 20 & 58,82 & 10 & 29,41 \\
4 & Kepuasan & 6 & 17,64 & 24 & 70,59 & 4 & 11,77 \\
\hline
\end{tabular}

Pada siklus I pertemuan 2, indikator perhatian (attention) dari 34 siswa terdapat 7 (20,59 $\%)$ siswa yang memiliki perhatian tinggi, $20(58,82 \%)$ siswa yang memiliki perhatian sedang, dan 7 (20,59\%) siswa yang memiliki perhatian rendah. Indikator kesesuaian (relevance) dari 34 siswa, terdapat $6(17,64 \%)$ siswa yang memiliki kesesuaian tinggi, 13 ( 38,24\%) siswa yang memiliki kesesuaian sedang, dan $15(44,12 \%)$ yang memiliki kesesuaian rendah. Indikator kepercayaan diri (confidence) dari 34 siswa terdapat $4(11,77 \%)$ siswa yang memiliki kepercayaan diri yang tinggi, $20(58,82 \%)$ siswa yang memiliki kepercayaan diri sedang, dan $10(29,41 \%)$ siswa yang memiliki kepercayaan diri rendah. Indikator kepuasan (satisfaction) dari 34 terdapat $6(17,64 \%)$ siswa yang memiliki kepuasaan tinggi, terdapat $24(70,59 \%)$ siswa yang memiliki kepuasan sedang, dan $4(11,77 \%)$ siswa yang memiliki kepuasan rendah.

Tabel 6. Skor Rata-rata

\begin{tabular}{c|l|c}
\hline No & \multicolumn{1}{|c|}{ Indikator } & rata-rata \\
\hline 1 & Perhatian & 2,42 \\
2 & Kesesuaian & 2,30 \\
3 & Kepercayaan & 2,34 \\
4 & Kepuasan & 2,44 \\
\hline
\end{tabular}




\begin{tabular}{c|c}
\hline Jumlah & 9,50 \\
Rata-rata & 2,38 \\
\hline
\end{tabular}

Pada siklus I pertemuan 2 jumlah skornya adalah 9,50 dengan rata-rata skor 2,38 yang artinya motivasi sedang. Pada pertemuan 2 di siklus I terdapat peningkatan skor rata-rata sebesar $21 \%$. Demikian juga dengan aktivitas guru dan siswa kualifikasinya semakin meningkat dari sebelumnya, akan tetapi ada yang belum dilakukan oleh guru, yaitu melatih siswa menerapkan metode problem solving sebelum siswa benar-benar mempraktikkan metode itu dengan lembar kerja siswa yang sudah disediakan.

Dengan diketahui motivasi belajar siswa pada pertemuan 1 dan 2, maka dapat diperoleh motivasi belajar siswa pada siklus I yaitu jumlah skor 9,08 dengan skor rata-rata 2,27, yang berarti bahwa motivasi belajar siswa masih sedang. Hal ini dikarenakan pada siklus 1 sebagaimana yang sudah dijelaskan di atas bahwa masih ditemukan beberapa kekurangan dalam proses pembelajaran dengan menggunakan metode problem solving

\section{Siklus 2}

\section{Pertemuan 1}

Pada siklus II pertemuan 1 ini, peneliti mengidentifikasi masalah yang ada pada siklus I yang mengakibatkan motivasi belajar siswa pada mata pelajaran PPKn masih dianggap kurang dan perlu terus ditingkatkan. Berangkat dari permasalahan itu peneliti merencanakan tindakan sebagai berikut.

a Pelaksanaan siklus II masih sama dengan siklus I yaitu menggunakan metode problem solving.

b Melakukan perbaikan Rencana Pelaksanaan Pembelajaran (RPP), dalam hal ini kompetensi berbeda dengan pertemuan pada siklus sebelumnya, yaitu tentang Upaya penegakan HAM di Indonesia, namun masih memiliki karakteristik yang sama dengan kompetensi sebelumnya.

c Penyusunan Lembar Kerja Siswa (LKS) sebuah kasus pelanggaran HAM yang terjadi di Indonesia.

d Pembuatan media yang berbentuk tabel yang berisi berbagai kasus pelanggaran HAM yang terjadi di Indonesia, kemudian siswa diminta mengidentifikasi kasus yang sudah mendapat penanganan dan yang tidak. Media ini dimaksudkan agar siswa lebih mengetahui upaya penegakan HAM yang telah dilakukan di Indonesia dan sekaligus melatih siswa dalam menerapkan metode problem solving sebelum siswa mengerjakan LKS sesuai dengan metode problem solving serta untuk menciptakan pembelajaran yang lebih menarik.

Pada tahap ini guru menyajikan skenario pembelajaran sesuai dengan yang telah direncanakan. Langkah-langkahnya sama seperti pada pertemuan-pertemuan sebelumnya yaitu pendahuluan, kegiatan inti, dan penutup. Hanya saja sebelum siswa mengerjakan LKS terlebih dahulu guru melatih siswa bagaimana menerapkan metode problem solving yang dilengkapi dengan media yang sudah dirancang oleh guru.

Tabel 7. Hasil Pengukuran Motivasi Belajar Siklus I1 Pertemuan 1

\begin{tabular}{llcccccc}
\hline No & \multicolumn{1}{c}{ Indikator } & \multicolumn{6}{c}{ Skor } \\
\hline & & Tinggi & $(\%)$ & Sedang & $(\%)$ & Rendah & $(\%)$ \\
\hline 1 & Perhatian & 13 & 38,24 & 18 & 52,94 & 3 & 8,82 \\
2 & Kesesuaian & 7 & 20,59 & 24 & 70,59 & 3 & 8,82 \\
3 & Kepercayaan & 7 & 20,59 & 26 & 76,47 & 1 & 2,94 \\
4 & Kepuasan & 13 & 38,24 & 17 & 50,00 & 4 & 11,77 \\
\hline
\end{tabular}

Pada siklus II pertemuan 1, indikator perhatian (attention) dari 34 siswa terdapat 13 $(38,24 \%)$ siswa yang memiliki perhatian tinggi, 18 (52,94\%) siswa yang memiliki perhatian 
sedang, dan $3(8,82 \%)$ siswa yang memiliki perhatian rendah. Indikator kesesuaian (relevance) dari 34 siswa, terdapat 7 (20,59\%) siswa yang memiliki kesesuaian tinggi, 24 ( 70,59 \%) siswa yang memiliki kesesuaian sedang, dan $3(8,82 \%)$ yang memiliki kesesuaian rendah. Indikator kepercayaan diri (confidence) dari 34 siswa terdapat $7(20,59 \%)$ siswa yang memiliki kepercayaan diri yang tinggi, $26(76,47 \%)$ siswa yang memiliki kepercayaan diri sedang, dan $1(2,94 \%)$ siswa yang memiliki kepercayaan diri rendah.

Tabel 8. Skor Rata-rata

\begin{tabular}{clc}
\hline No & \multicolumn{1}{c}{ Indikator } & rata-rata \\
\hline 1 & Perhatian & 2,74 \\
2 & Kesesuaian & 2,65 \\
3 & Kepercayaan & 2,75 \\
4 & Kepuasan & 2,82 \\
& Jumlah & 10,96 \\
& Rata-rata & 2,74 \\
\hline
\end{tabular}

Pada siklus II pertemuan 1 jumlah skornya adalah 10,96 dengan rata-rata skor 2,74 yang artinya motivasinya sedang. Pada siklus II pertemuan 1 ini, motivasi belajar siswa pada mata pelajaran PPKn mengalami peningkatan. Hal ini dapat dilihat dari skor rata-rata pada siklus I adalah 2,27, sedangkan pada siklus II pertemuan 1 skor rata-rata sebsar 2,74. Berarti ada peningkatan sebesar $47 \%$. Berdasarkan hasil observasi aktivitas guru dan siswa, peningkatan ini terjadi karena guru dalam menerapkan metode problem solving dilengkapi dengan sebuah media pembelajaran yang dapat melatih siswa dari mulai mengidentifikasi masalah sampai pemecahannya, yang menjadikan pembelajaran lebih menarik dan aktivitas siswapun menjadi semakin meningkat. Sehingga saat menerapkan metode problem solving melalui lembar kerja siswa yang diberikan oleh guru menjadi lebih lancar dari sebelumnya karena siswa sudah semakin paham terhadap metode problem solving. Walaupun sudah ada peningkatan pada siklus II pertemuan 1 ini, namun peningkatan motivasi belajar masih tetap dalam kategori sedang. Hal ini disebabkan karena masih adanya beberapa siswa yang mendapat skor rendah yaitu rata-rata pada indikator perhatian, kesesuaian, percaya diri, dan kepuasan, yang berarti masih ada beberapa siswa yang memiliki motivasi rendah dalam proses pembelajaran.

\section{Pertemuan 2}

Pertemuan 2 siklus II ini dilakukan untuk menyempurnakan apa yang sudah dicapai pada pertemuan 1 agar motivasi belajar siswa dalam mata pelajaran PPKn lebih meningkat lagi. Pada pertemuan 2 tidak banyak perbedaan langkah-langkah yang ditempuh dalam penerapan metode problem solving, yaitu sebagai berikut.

a Melakukan perbaikan Rencana Pelaksanaan Pembelajaran (RPP), dalam hal ini kompetensi berbeda dengan pertemuan sebelumnya, yaitu tentang hambatan dan tantangan penegakan HAM. Kompetensi ini memiliki karakteritik sama dengan kompetensi pada pertemuanpertemuan sebelumnya.

b Penyusunan Lembar Kerja Siswa (LKS) yang berupa cerita singkat tentang hambatan dan tantangan upaya penegakan HAM di Indonesia.

c Pembuatan media hampir sama dengan media pada pertemuan sebelumnya hal ini dilakukan karena dengan media tersebut sangat membantu siswa dalam menerapkan metode problem solving. Hanya saja isi materi dan teknik penggunaannya yang berbeda. Setelah menempelkan kartu-kartu tersebut siswa diminta memberikan penjelasan sesuai dengan kartu yang dipilih oleh siswa. Hal ini berbeda dengan pertemuan sebelumnya yang setelah menempelkan kartu hanya ditanya tepat atau tidak.

Tabel 9. Hasil Pengukuran Motivasi Belajar Siklus I1 Pertemuan 2 


\begin{tabular}{clcccccc}
\hline No & \multicolumn{1}{c}{ Indikator } & \multicolumn{8}{c}{ Skor } \\
\hline & & Tinggi & $(\%)$ & Sedang & $(\%)$ & Rendah & $(\%)$ \\
\hline 1 & Perhatian & 24 & 70,59 & 10 & 29,41 & - & 0 \\
2 & Kesesuaian & 23 & 67,65 & 11 & 32,35 & - & 0 \\
3 & Kepercayaan & 26 & 76,47 & 8 & 23,53 & - & 0 \\
4 & Kepuasan & 27 & 79,41 & 7 & 20,59 & - & 0 \\
\hline
\end{tabular}

Pada siklus II pertemuan 2 berdasarkan tabel 4.15, indikator perhatian (attention) dari 34 siswa terdapat $24(70,59 \%)$ siswa yang memiliki perhatian tinggi, $10(29,41 \%)$ siswa yang memiliki perhatian sedang, dan tidak ada siswa yang memiliki perhatian rendah. Indikator kesesuaian (relevance) dari 34 siswa, terdapat $23(67,65 \%)$ siswa yang memiliki kesesuaian tinggi, 11 ( $32,35 \%$ ) siswa yang memiliki kesesuaian sedang, dan tidak ada siswa yang memiliki kesesuaian rendah. Indikator kepercayaan diri (confidence) dari 34 siswa terdapat 26 $(76,47 \%)$ siswa yang memiliki kepercayaan diri yang tinggi, $8(23,53 \%)$ siswa yang memiliki kepercayaan diri sedang, dan tidak ada siswa yang memiliki kepercayaan diri rendah. Indikator kepuasan (satisfaction) dari 34 terdapat $27(79,41 \%)$ siswa yang memiliki kepuasaan tinggi, terdapat 7 (20,59\%) siswa yang memiliki kepuasan sedang, dan tidak ada siswa yang memiliki kepuasan rendah.

Tabel 10. Skor Rata-rata

\begin{tabular}{clc}
\hline No & \multicolumn{1}{c}{ Indikator } & rata-rata \\
1 & Perhatian & 3,32 \\
2 & Kesesuaian & 3,24 \\
3 & Kepercayaan & 3,30 \\
4 & Kepuasan & 3,34 \\
& Jumlah & 13,20 \\
& Rata-rata & 3,33 \\
\hline
\end{tabular}

Pada pada siklus II pertemuan 2 jumlah skornya adalah 13,20 dengan rata-rata skor 3,33 yang artinya motivasi tinggi. Angka ini menunjukkan bahwa motivasi belajar siswa pada mata pelajaran PPKn pada pertemuan 1 ke pertemuan 2 dalam siklus II mengalami peningkatan, yaitu sebesar 59\%. Demikian juga dengan aktivitas guru dan siswa kualifikasinya semakin meningkat dari sebelumnya. Berdasarkan hasil pengamatan aktivitas guru dan siswa, peningkatan ini terjadi karena siswa sudah semakin paham terhadap metode problem solving dan pembelajaran yang disajikan oleh guru juga cukup manarik karena dilengkapi dengan media pembelajaran dengan teknik penggunaannya yang cukup bervaristif dari pertemuan sebelumnya.

Setelah diketahui motivasi belajar siswa pada pertemuan 1 dan 2, maka dapat diperoleh motivasi belajar siswa pada siklus II yaitu jumlah skor 12,09 dengan skor rata-rata 3,02, yang berarti bahwa motivasi belajar siswa tinggi. Hal ini menunjukkan bahwa penelitian sudah mencapai indikator keberhasilan yaitu skor rata-rata motivasi belajar siswa lebih dari 3,00.

\section{Pembahasan}

Penelitian tindakan kelas ini dilakukan dalam kurun waktu kurang lebih tiga bulan, yaitu sejak pertengahan Juli sampai Oktober 2018. Proses pembelajaran dilaksanakan dengan menggunakan metode problem solving yang dilakukan dengan dua siklus dan tiap siklusnya dua kali pertemuan dengan materi menganalisis kasus-kasus pelanggaran hak asasi manusia dalam rangka perlindungan, pemajuan, dan pemenuhan hak asasi manusia.

Hasil penelitian menunjukkan ada peningkatan motivasi belajar siswa pada setiap siklusnya. Hal ini dapat dilihat dari perbandingan perolehan skor pada tabel berikut. 


\section{Tabel 11. Perbandingan Skor Rata-rata Motivasi Belajar pada Pratindakan, Siklus I,} dan Siklus II

\begin{tabular}{clccc}
\hline \multirow{2}{*}{ No } & \multirow{2}{*}{ Indikator } & \multicolumn{3}{c}{ Skor Rata-rata } \\
& & Pratindakan & Siklus I & Siklus II \\
\hline 1 & Perhatian & 2,00 & 2,32 & 3,03 \\
2 & Kesesuaian & 1,92 & 2,20 & 2,95 \\
3 & Kepercayaan & 1,98 & 2,27 & 3,03 \\
4 & Kepuasan & 1,90 & 2,29 & 3,08 \\
& Jumlah & 7,80 & 9,08 & 12,09 \\
& Rata-rata & 1,95 & 2,27 & 3,02 \\
\hline
\end{tabular}

Berdasarkan tabel 11, kondisi awal pada pratindakan menunjukkan motivasi belajar mencapai jumlah skor 7,80 dengan skor rata-rata 1,95, yang artinya motivasi belajar siswa dalam mata pelajaran PPKn masih rendah. Salah satu yang mempengaruhi rendahnya motivasi belajar siswa adalah proses pembelajaran yang digunakan cenderung bersifat konvensional. Pengajar lebih merupakan subyek dalam pembelajaran, sedangkan siswa hanya sebagai obyek penerima materi. Dengan kondisi pembelajaran yang demikian siswa menjadi kurang tertantang untuk berpikir, merasa bosan dan tidak tertarik, dan lebih banyak pasif.

Pada siklus I jumlah skor 9,08 dengan skor rata-rata 2,27. Berarti ada peningkatan motivasi belajar siswa sebesar $32 \%$. Namun motivasi belajar siswa masih dalam kategori sedang, hal ini dikarenakan siswa masih belum memahami dan belum terbiasa menerapkan metode pembelajaran problem solving, sehingga guru sebagai fasilitator dan motivator berupaya untuk memahamkan siswa agar dapat mengikuti kegiatan pembelajaran dengan metode problem solving melalui berbagai cara, yaitu memberikan contoh, melatih, dan melengkapi dengan media pembelajaran yang membantu siswa dalam memahami metode problem solving.

Pada siklus II guru melakukan perbaikan-perbaikan dalam aktivitas pembelajaran sehingga siswa mulai paham terhadap metode problem solving, aktiviatas siswapun menjadi meningkat, dan jumlah skor mencapai 12,09 dengan skor rata-rata 3.02 berada dalam kategori tinggi. Pada siklus II ini motivasi belajar siswa dalam pembelajaran PPKn mengalami peningkatan yang cukup signifikan yaitu sebesar $75 \%$.

Berdasarkan hasil analisis data yang diperoleh, maka dua permasalahan yang diangkat dalam penelitian ini telah terjawab yaitu pertama, bahwa pembelajaran dengan menggunakan metode problem solving dapat meningkatkan motivasi belajar siswa pada mata pelajaran PPKn. Temuan ini sejalan dengan hasil penelitian Septiana dan Zaini (2021) yang menyatakan bahwa terdapat pengaruh dari layanan kelompok dengan teknik problem solving terhadap motivasi belajar peserta didik. Hal tersebut juga didukung oleh pendapat Hermawati, Nur D.S., dan Yuni (2020) dalam penelitiannya yang mengatakan bahwa terdapat pengaruh yang signifikan penerapan model problem solving terhadap motivasi belajar.

Kedua, Peningkatan motivasi belajar siswa disebabkan oleh adanya peningkatan kualitas dalam proses pembelajaran. Dengan menggunakan metode problem solving dalam pembelajaran PPKn, aktivitas siswa menjadi meningkat. Hal ini dikarenakan dengan metode problem solving siswa dituntut untuk melakukan aktivitas-aktivitas yang membuat siswa menjadi lebih aktif, kritis dan kreatif dalam berpikir serta terlatih dalam menemukan dan memecahkan masalah-masalah yang dihadapi. Sebagaimana pendapat Silayusa, Dantes, dan Suami (2015), bahwa pembelajaran dengan metode problem solving dapat meningkatkan kemampuan berpikir kritis peserta didik, karena metode tersebut menekankan pada kemampuan untuk dapat memecahkan suatu permasalahan sehingga kemampuan berpikir kritis peserta didik akan terus terlatih. Sedangkan Sholeh, Riyanto, Bachri (2021) dalam penelitiannya, 
menyatakan bahwa pembelajaran konstruktivistik dengan metode problem solving berpengaruh terhadap kreativitas siswa. Dari sini jelas bahwa semakin kreatif siswa maka akan semakin meningkat aktivitasnya, dan hal ini merupakan indikasi bahwa motivasi belajar siswa tinggi dalam pembelajaran PPKn. Sesuai dengan hasil penelitian Eltafiyana et al. (2018) yang menyatakan bahwa ada hubungan yang signifikan antara kemampuan berpikir kreatif matematis dan motivasi belajar siswa. Bahwa pembelajaran dengan menggunakan metode problem solving dapat meningkatkan kemampuan berpikir kritis peserta didik, karena metode tersebut menekankan pada kemampuan untuk dapat memecahkan suatu permasalahan sehingga kemampuan berpikir kritis peserta didik akan terus terlatih. Model pembelajaran problem solving dapat meningkatkan kemampuan berpikir dan aktivitas belajar siswa (Kristiawan, Toenlioe, \& Sulthoni, 2016)

\section{KESIMPULAN}

berikut:

Berdasarkan hasil penelitian dan pembahasan dapat diambil kesimpulan sebagai

1. Penggunaan metode problem solving dapat meningkatkan motivasi belajar siswa pada mata pelajaran PPKn kelas XI MIPA-3 MAN 1 Jember. Hal itu ditunjukkan dengan adanya peningkatan motivasi belajar siswa dari pratindakan, siklus I dan siklus II. Pada tahap pratindakan pembelajaran menggunakan metode konvensional yaitu ceramah dan pemberian tugas sehingga siswa kurang tertarik dalam mengikuti pelajaran. Pada pratindakan motivasi belajar siswa dalam mata pelajaran PPKn jumlah skor mencapai 7,80 dengan skor rata-rata 1,95 yang artinya motivasi belajar rendah. Pada siklus I pembelajaran dengan motode problem solving, motivasi belajar siswa dalam mata pelajaran PPKn mengalami peningkatan tetapi masih dalam kategori sedang, yaitu dengan jumlah skor mencapai 9,08 dan skor ratarata 2,27 yang artinya motivasi belajar sedang. Pada siklus II proses pembelajaran tetap menggunakan metode problem solving akan tetapi dilengkapi dengan media pembelajaran yang teknik penggunaanya berbeda dengan pertemuan sebelumnya yang menjadikan siswa lebih paham terhadap penerapan metode problem solving, sehingga pada siklus II motivasi belajar siswa dalam mata pelajaran PPKn mengalami peningkatan yang cukup signifikan yaitu jumlah skor mencapai 12,09 dengan skor rata-rata 3,02 yang artinya motivasi belajar tinggi.

2. Penerapan metode problem solving dalam meningkatkan motivasi belajar siswa pada mata pelajaran PPKn dilakukan dengan mengikuti langkah-langkah, yaitu identifikasi masalah, menetapkan masalah, mengembangkan alternatif, menetapkan alternatif dan menarik kesimpulan. Proses pelaksanaan metode problem solving ini menggunakan media lembar kerja siswa (LKS). Lembar kerja siswa berisi satu masalah, kemudian siswa diminta untuk melakukan langkah-langkah problem solving. Setelah selesai berdiskusi kelompok, masingmasing kelompok melakukan presentasi dan kemudian ditanggapi kelompok lain. Model pembelajaran problem solving akan merangsang siswa untuk berpikir, membuat siswa lebih antusias dalam mengikuti pelajaran karena merasa tertantang untuk memecahkan masalah yang dihadapi. Peningkatan motivasi belajar siswa dapat dilihat dari indikator attentision (perhatian), relevance (kesesuaian), confidence (kepercayaan diri) dan satisfaction (kepuasan).

\section{DAFTAR PUSTAKA}

Dewi, A.N.A. Rudibyani, R.B. Efkar, T. 2018. Efektivitas Problem Solving untuk Meningkatkan Motivasi Belajar dan Penguasaan Konsep Materi Elektrolit/ Non Elektrolit. Jurnal Pendidikan dan Pembelajaran Kimia (JPPK). Vol. 7 No. 2. 2018. FKIP. Unila.

Djajadisastra, J. 1982. Metode-Metode Mengajar. Bandung: Angkasa.

Eltafiyana, S. Nurjanah, S.A. Armania, M. Sugandi, A.I. Fitriani, N. 2018. Hubunagn Antara Kemampuan Berpikir Kreatif Matematis dan Motivasi Belajar Siswa Yang 
Menggunakan Pendekatan Creative Probelem Solving. Jurnal Teorema. Vol. 2 No. 2. 2018. Unigal. Ciamis.

Hamdani. 2011. Strategi Belajar Mengajar. Bandung: CV. Pustaka Setia

Hermawati. NurDS, Y. Yuni, D.V. 2020. Pengaruh Model Problem Solving Terhadap Motivasi Belajar. Jurnal Sekolah Dasar. Vol. 5 No. 1. 2020. Universitas Buana Perjuangan. Karawang

Kristiawan. I. Toenlioe, A.J.E. Sulthoni, S. 2016. Penerapan Pembelajaran Problem Solving Pada Mata Pelajaran pendidikan Kewarganegaraan untuk Meningkatkan Keterampilan Berfikir dan Aktivitas Belajar Siswa. Jurnal2 um. Vol. 3 No. 1. 2016. Universitas Negeri Malang.

Mukhlis. 2017. Meningkatkan Motivasi Belajar Mahasiswa Melalui pembelajaran Model Problem Solving Materi Stoikiometri. Jurnal Lantanida. Vol. 5 No. 2. 2017. UIN ArRaniry. Banda Aceh.

Mukhlisoh, Aisah, S. 2014. Pengaruh Penerapan Metode Problem Solving terhadap Motivasi Belajar Siswadalam Mata Pelajaran IPS Kelas IV MI PUI Cikaso Kecamatan Kramatmulya Kabupaten Kuningan. Jurnal Pendidikan Guru MI. Vol. 1 No. 2. 2014. IAIN Syekh Nurjati. Cirebon.

Septiana, D. Zaini, A.A. 2021. Pengaruh Layanan Bimbingan Kelompok dengan Tehnik Problem Solving Terhadap Motivasi Belajar Peserta Didik di MA Ma'arif 17 Tarbiyatus Shibyan. Jurnal Lantanida. Vol. 1 No. 2. 2021. Insud. Lamongan.

Sholeh, A. Riyanto, Y. Bachri, S. 2021. Pengaruh Pembelajaran Konstruktivistik dengan Metode Problem Solving Terhadap Terhadap Kreativitas Siswa MAN. Jurnal Teknologi Pendidikan. Vol. 6 No. 2. 2021. Uika. Bogor.

Silayusa, N.P. Dantes, N. Suami, N.K. 2015. Pengaruh Pembelajaran Problem Solving Berbantuan Media Audio terhadap Motivasi Belajar dan Pestasi Belajar IPS Siswa SMALBdi SLB A Negeri Desnpasar. Jurnal Program Pascasarjana. Vol. 5 No. 1. 2015. Universitas Pendidikan Ganesha. Singaraja.

Peraturan Pemerintah Republik Indonesia No. 32 Tahun 2013 tentang Perubahan Peraturan Pemerintah No. 19 Tahun 2005 tentang Standar Nasional Pendidikan. Jakarta: Presiden RI 